\title{
Gender inequality: The problem of harmful, patriarchal, traditional and cultural gender practices in the church
}

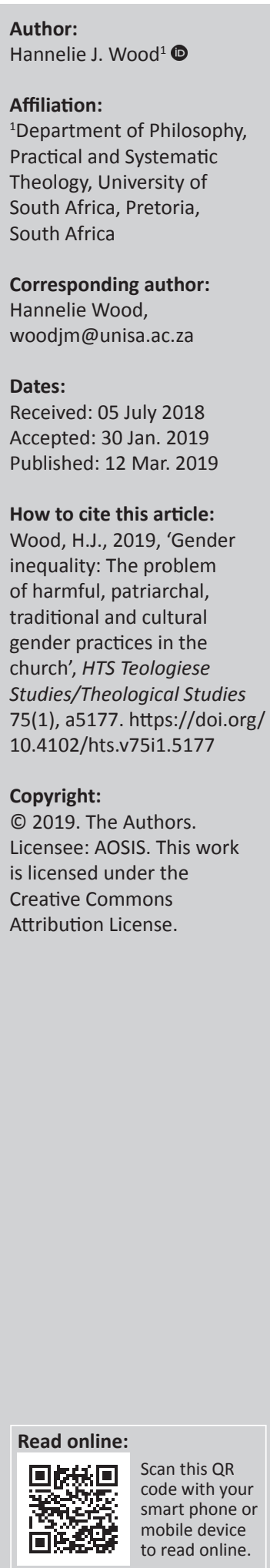

This article aims to look at the church's role in the formation and up-keeping of gender inequality, and how it shaped and constrained gender equality through a stereotypical lens. Harmful and traditional cultural practices contribute to women's suffering and often result in violence in the patriarchal context. This caused women to renegotiate their identities amidst the church's views on women and their accepted social roles. Secondly, focus will be placed on gender inequality in the African context. Lastly, I will argue that the church has to confront its views on gender inequality and how it can sanction women's equality, whereafter I will propose a metaphor for the church as the tree of gender equality.

\section{Introduction}

According to Genesis 1:26-31, God created humankind. He created them as male and female in his image, and after God blessed them, he saw that everything he had made was good; indeed it was very good. Both male and female were called to rule, to multiply and to nurture children.

The following is a story told by Kimball (2004) that speaks to equality. She states that she heard a story that Sister Joan Chittister once told:

A merchant in the Middle East went from bazaar to bazaar buying rugs to export. One day he passed a stall where an elderly woman sat on a tiny rug before a very large hand-woven rug. He asked the old lady whether the rug behind her was for sale. Without looking up she answered that it is for sale. He asked her how much she wanted for the rug on which she replied: 'One hundred rupees, sir. One hundred rupees'. Again he asked her to confirm the price on which she replied: 'One hundred rupees. Not a single rupee less'. He looked at her and said: 'Old lady, I have never seen a rug that beautiful'. She nodded and said: 'I know that, sir. That's why I'm selling it for One hundred rupees and not a single rupee less'. The merchant then said: 'In the name of Allah, old lady, if you realize how beautiful your rug is, why would you ever sell it for only one hundred rupees?' Shocked at this question the old lady looked up for the first time, and after a moment of silence she answered: 'Because, sir, until this very moment, I never knew that there were any numbers above 100 '. (pp. 464-467)

With Chittister's story in mind, Kimball (2004:465) states that the story implies that when people are kept ignorant of their abilities it comes at a terrible cost. This is also true about gender inequality. She also says that every gender and class stumbling block was broken when Peter in Acts 2:17 said that in the last days sons and daughters will prophesy and that the Spirit will be poured out on both men and women. There are numbers above 100, and women may not remain ignorant of their strengths and equality such as the woman in the preceding story.

Inequality presents and manifests as one of the most prevalent forms of social construction all over the world (Klingorová \& Harvlíček 2015:2), and it can be defined as culturally and socially created differences between men and women when both sexes do not have the same share in the decisionmaking and wealth of a society (Ridgeway 2004:510). Inequality is the result of cultural and historical developments, geographic setting and religious customs predominant in society (Stump 2008). This is also true about faith communities. This brings us to a brief look at the old problem of patriarchy.

\section{The problem of patriarchy}

There are numbers above 100, and the church may not remain tenaciously ignorant of women's inequality. The marginalisation, oppression and inequality of women are as old as biblical history itself. Wood (2012) states:

Note: Christina Landman Festschrift, sub-edited by Wessel Bentley (University of South Africa) and Victor S. Molobi (University of South Africa). 
History teaches us what people before us did, what their intentions were and where they failed or went wrong. If historical viewpoints about women reflect women's subordination and oppression, they force women to discover their roots and their past. (p. 1)

Patriarchy presented and shaped societies in the history of humanity, both in the past and the present. Patriarchy has been a mode of life and is considered ahistorical, eternal and endorsed by God.

In her book, Beyond Power: On women, men and morals (1985:16), Marilyn French argues that, historically, women's oppression and marginalisation amounted to a form of slavery. She contends that slavery in a patriarchal state occurs when women do not have the rights to their own bodies, sexuality, marriage, reproduction, divorce, education, when they are excluded from practising a trade or profession and when their freedom of movement is restricted.

Because the roots of patriarchy run so deep in the fabric of society, it is difficult to change, because patriarchy is so deeply rooted in the principles of control, male dominance, identification and centeredness. The following metaphor of a tree from Johnson's The Gender Knot (2014:18-20) is very helpful in our discussion and understanding of patriarchy.

According to Johnson (2014:28), the roots of the tree represent the core of patriarchy, where male dominance, centrism and control are located. The roots demonstrate a deep-rooted male control that is very complex and hard to disentangle or remove.

The trunk resembles those social institutions that shape and support patriarchy. We participate daily in institutions such as education, politics, science, art and the economy that are built on patriarchal roots (Johnson 2014:17). This includes faith-based institutions that are responsible for how women are perceived and valued.

The branches illustrate the way in which individuals interact with patriarchy, and according to Johnson (2014) it affects all spheres of our lives: communities, legal structures and families. This is, of course, applicable to the church and how women react against patriarchy in the church.

The leaves resemble a passiveness that does not object to being part of the tree, but humans are not always passive and often separate themselves from the tree. That is when the whole system will lose its power and die (Johnson 2014:17-18). In the church, women often have to result to actions to separate themselves from the patriarchal dogma that still prevails in the church.

With the tree metaphor, Johnson wants to illustrate that it is not simple to break the link between patriarchy and the individual, and in order to refute patriarchy, one has to start with the roots; thus society has to look into and question patriarchy, its underpinnings and the knowledge that shapes it.
As an ideology, patriarchy upholds the view that the male has superior control over women and all others under their care. Culture, religion, social structures, the media and educational institutions have played a major role in the creation and perseverance of the patriarchal ideology.

Patriarchy is at its core evil, repressive and oppressive, and needs to be contested and exploited for what it stands for. Being a supremacist ideology, patriarchy promotes male supremacy in the spiritual and physical realms as well as in social and personal spheres.

The spheres in which patriarchy wants to control religious discourse are marriage, church leadership, intimate bodies, desire, and family and household, says Landman (2009:40). She further states that patriarchy promotes the idea that marriage according to the Bible is between a dominant male and his subordinate female; the church, a body of Christ, is male and women are therefore excluded from leadership roles; women's bodies are sinful; desire and sex are only for reproduction; and within the family and household, women are to be subordinate because it is God's will that men are to be the head thereof (Landman 2009:40-42).

Within faith communities, patriarchy is one of the main stumbling blocks that prevent women to be fully equal to men in their own right. Generally, the concept of patriarchy is denoted as the 'rule of men over women', and mostly it refers to economic, political, social and religious ideologies that have enforced the domination of women (Jones 2000:77). Patriarchy, as a discriminatory force, has a long history that sweeps across national and cultural boundaries and is a system that constrains women by means of male dominance (Maseno \& Kilonzo 2011:45). Patriarchy is, as a social system, inherited by men, and it is passed on from father to son. It is a system in which men dominate, oppress and exploit women. Patriarchy extends beyond the household to society in general. Family members are dependent on, and submissive to, the male head of the household (Laurien 2004:1).

Patriarchy is 'a hierarchical system of social organization whereby men hold positions of power over women', and it is a powerful ideology because men are conditioned to secure the consent of the women they oppress. This is often done with the approval of the church, which causes women to '[internalise] a sense of inferiority to men' and when this very conditioning of their inferiority to men is not accepted by women, men resort to 'coercion, intimidation and violence' (Madlala-Routledge 2009:4).

\section{The problem of gender stereotyping and gender inequality}

Gender inequality and stereotyping are an integral part of history and go all the way back to Adam and Eve in the Genesis story. Eve was made from and for Adam, and as the lesser of the two created genders she persuaded Adam to eat the forbidden fruit. This was and is still today enough reason to justify the lower status of women by the church. 
Stereotypical generalisations are passed on from one generation to the other and include ideas such as that women are born with inferior status; women are Eve incarnated; girls are seen as property; men and women are not equal; men are superior because God ordained them to be superior; sin originates from women's embedded wickedness and weakness; and women may not be leaders because of their fragility. Endendijk et al. (2013:1) state that gender stereotypes are 'widely held beliefs about the characteristics, behaviours, and roles of men and women', and Louw (2009) postulates that:

... hierarchy is underpinned by four interlocking justifications namely biological (that male physical strength is part of intended natural law); cultural (that families and societies are naturally based on aggression, domination, procreation and spouse and child protection); economic (that property, production and distribution of goods are the natural domain of men); religious (that male superiority, dominance and privilege are part of received religious revelation). (p. 99)

Stereotyping women holds back their full potential and must be labelled as one of the worst forms of violence against women. Not only does it get in the way of women participating fully and equally in all spheres of their lives, it also demeans and lessens women's dignity. Stereotyping women results in them being marginalised and discriminated against, which brings about unfair and inequitable conduct against them whilst their human rights are being constrained.

Although I am mindful of the many variations of, and definitions for, the term 'gender', it remains for many people a vague term that is often understood as something for women by women or merely being male or female. The term, however, helps us to identify power struggles between men and women in order for us to understand ourselves as well as others to achieve positive transformation.

Broadly speaking, the term 'gender' refers to the socially constructed differences that assign the attitudes and opportunities of males and females and their social interaction and relationships between them. It also determines what is accepted, permitted and valued for both women and men at any given time, and it differs from context to context, thus being context-specific.

For the purpose of this article, it is necessary to clarify what I am speaking about in my discussion of gender. I find the following definition very helpful:

Gender is social status, a legal designation, and a personal identity. Through the social processes of gendering, gender divisions and their accompanying norms and role expectations are built into the major social institutions of society, such as the economy, the family, the state, culture, religion, and the law - the gendered social order. Woman and man, girl and boy are used when referring to gender. (Lorber 2010:15)

Gender inequality is as old as the history of the Bible. The church, philosophical standpoints, superstition and man-made traditions are all role players in how gender equality is perceived. Collins (2010:76) is of the opinion that transformative imagery and symbolic language, as studied by scholars, 'has been shown to be reflective of Biblical imagery and the Jewish and Christian understanding of apocalypse and eschatology'. In her reflection on gender, Njoroge (2009) states that:

Historically, gender roles - the socially constructed roles of women and men - have been ordered hierarchically, with men exercising power and control over women. Male dominance and female subordination have both ideological and material bases. Patriarchy has been entrenched in social, religious and cultural norms, institutionalized in the law and political structures and embedded in local and global economies. It has been ingrained in formal ideologies and in public discourse. Patriarchy restricts women's choices but does not render women powerless, as evidenced by the existence of women's movements and successful claims by women for their rights. (p. 4)

Dominance and control over others bring about destructive consequences in God's creation. Gender inequality is one such a destructive force that the church has to confront in order to transform and to heal women from the plague of gender subordination. The creation and fall narratives in Genesis are often used as a double bind for women: firstly to subjugate them and secondly to blame them for their subjugation. Although women were historically present and active in the church, their true stories have been forgotten and not found in the main narrative of the church. De Conick (2011:147) states that it is even more disturbing that 'authentic memories of women in the early church were intentionally replaced with misogynist narratives' and that 'misogynist narratives were made sacred or holy'.

Women's bodies and the oppression, marginalisation, vilification and the othering thereof in early Christianity is one of the most dishonourable teachings of traditional Christianity. De Conick (2011:147) says that the 'story of women in the early church is far from easy to understand' because of 'ancient sources that obstructed our views' of women's stories, which have been 'marginalized, overwritten, or even erased by the authors of the surviving texts'. She also contends that 'recorded women stories in the ancient sources cannot be understood at face value since texts were written by males'. This was because of the fact that males in the churches had their own interests and authority upfront.

The Bible, as one of the important sources of the Christian faith, is interpreted by many people in different ways including that of gender inequality and stereotyping. Women are portrayed in the Bible as secondary role players in God's plan for humanity; as background figures; as being destructive and harmful to men; and not made in the image or character of God (Hadebe 2007). In early Christianity, women were subjected to evidential change, and over centuries their roles waxed and waned as political structures in Western European societies changed from tribal to kingdoms (Remedios 2016:7).

As the church became more bureaucratic, it also became more insensitive regarding gender. For example, the titles of 
priest and priestess were originally not used in the church because they originated from pagan religions of the classical world. The church, however, later added the title of the priest but not that of priestess, and women were given the title of deaconess, which is indicative of the church's views on women's lower status. Women were later prohibited from administering the sacrament of baptism - an attempt of the Orthodox Church to rid Christianity of Gnosticism. In this regard, the church argued that if Jesus wanted women to baptise he would have wanted his mother to baptise him. With regard to the ordination of women, the church often used the arguments that Jesus only appointed male disciples, that Paul ordered women to be silent in the church and that they are not allowed to teach (MacDonald 2010:76).

The early church fathers used texts from the Bible to legitimate the marginalisation and subordination of women. Texts such as Genesis 1:27, Genesis 2:20-23 and Genesis 3:1-24 in the Old Testament and New Testament scriptures 1 Timothy 2:8-15, 1 Corinthians 11:7-9, 1 Corinthians 14:33-35 and Ephesians 5:22-23 were regularly cited and used to oppress women.

In the New Testament, for example, we find examples of women's presence as leaders, followers and mothers who contributed to the development of Christian theology and praxis. Their attraction to Christianity offered them a sense of self-identity as Christians (Remedios 2016:8).

However, women's leadership was later declared heretical, and the evidence of their leadership roles was erased and suppressed in many ways: for example, prophetic oracles were destroyed and texts were changed. This caused and played a part in the disappearance of women's status. Tertullian, Origen, Chrysostom, Jerome and Augustine are amongst the influential church fathers who promoted the inferiority of women as well as their submission to men. Their ideas about women were later injected into the message of the New Testament, which resulted in women becoming more marginalised and subordinate (Macdonald 2010:76).

Witherington says that it was Jesus himself who openly and publicly went against the grain of the social norms of his time. For example, he openly reached out to women such as Mary Magdalen, a prostitute, and the Samaritan woman at the well. He also reached out to those unnoticed women such as Peter's mother-in-law, the woman who touched his garment, the widow of Nain and Jairus' daughter. He also presented women such as Zarephath's widow, the Queen of the South and the poor woman's offering as models of faith. Furthermore, Jesus told parables about women such as the parable of the lost coin and the Leaven. The parables of the lost sheep and the mustard seed point to the growth of God's Kingdom in terms of women and their domestic work (Witherington 1985:39-41).

These acts of Jesus clearly show how Jesus defied the patriarchal mindset about women and his refusal to bend to Pharisaic pressures of his time. Jesus reacted against the patriarchal mentality based on sexual differences by calling women to follow him in his ministry (Collins 2010:87).

One of the worst forms of power over women is the upholding of gender inequality and stereotyping that degrades, devalues, disregards and hinders women's equal contribution and involvement in the public and private spheres of life. It is also true that traditional gender roles and stereotypes have a powerful influence on the division of gender roles. These divisions are often visible at home, in the workplace and in society.

I acknowledge that the church is not a homogenous entity and that differences of opinion about gender equality do exist in the church, but whilst we witness that gender equality in the workplace is growing, we often experience that some churches still resist gender equality. Pierce and Groothuis (2004:13) contest that the difference between men and women do [sic] not justify granting men unique and perpetual prerogatives of leadership and authority not shared by women'.

Wood (2012) states:

We find numerous texts in the Bible that deal with the differences between men and women and their different roles. However problematic these texts may be, they do not represent a checklist for stereotyping what each gender should do or not do. Instead, they teach us how to relate to each other in, and through, God. (p. 177)

Having briefly explored gender inequality and stereotyping of women in history, we turn now to the position of women in South Africa and their endeavours to resist their isolation and inequality bestowed upon them through harmful patriarchal traditions and cultural practices.

\section{The problem of harmful patriarchal traditional and cultural gender practices in the church}

Culture as a sociocultural variable is a socially perceived set of characteristics that distinguish between male and female and determine what is expected and what the allowed values between males and females are. Gender roles are learned through socialisation and are instituted by systems such as education, politics, economy, legislation, culture and tradition (Omoyibo \& Ajayi 2011:3743).

Livermore (2009:80-81) defines 'culture as a pattern of thinking, feeling and reacting to various situations' and, according to Owanikin (2006:209),'prejudice concerning the status of women in the church can be rooted in culture'. Theron (2015) states:

There can also be little doubt that the dominating culture in which a church finds itself is exerting influence on it. It is very possible that some cultural norms and practices may have entered a church and are shaping - consciously or unconsciously - its actions and decisions, causing suffering to those who usually form the largest part of its membership, the women. (p. 55) 
In a patriarchal context, religious arguments that manifest into harmful traditional and cultural practices are used to support injustice towards women. For example, prescriptive dress codes keep women invisible; they are restricted in their movements in the private and public spheres and therefore also restricted from holding positions of authority in the church. Women are often constrained from receiving education and from working outside the home, and their rights are violated in their choice of marriage partner, whether to have or not to have children, to divorce and to express themselves sexually (Jeffreys 2002:2000).

'Africa did not protect its women', says Shonayin (2012:98), and she reports 'that generation after generation the same old mistakes are repeated because atrocities and injustice against women are justified by traditional beliefs'. Traditional and cultural practices can be harmful to women's health; they cause material differences; they create the dire situation of women being viewed as being available for the benefit of men; and they create stereotypical masculinity and femininity, which hamper women's equal rights.

Harmful traditional and cultural practices within the family manifest as violence, genital mutilation, honour killings, early marriage, polygamy and covering. Statistics South Africa (2017) in their South Africa Demographic and Health Survey 2016: Key Indicator Report notes:

Based on questions about domestic violence against women 18 years and older, $21 \%$ of ever-partnered women reported that they had ever experienced physical violence by a partner, and $8 \%$ reported that they experienced physical violence in the past 12 months. Furthermore, $6 \%$ of ever-partnered women reported that they ever experienced sexual violence by a partner, and $2 \%$ experienced sexual violence in the past 12 months. (p. xiv)

Gender-based violence is a violation of human rights. Despite constitutional protections, gender-based violence remains persistent and widespread in South Africa (DWCPD 2014). Violence against women occurs across socioeconomic status, race, age, and religion. (p. 53)

On 22 May 2017, Iavan Pitoos, from News24, reported that 'South Africa is a country where women and children end up as grim stats'. In his article, he writes that an alarming number of women and children have been killed in South Africa and that these killings are committed by those women's boyfriends or by men they knew. He also states that, according to the SA Medical Research Council, a woman is killed every 8 hours, and one in five women experience physical violence by a partner. He reports, amongst others, that 20-year-old Karabo Mokoena's body was found in Bramley, necklaced and with acid poured over her; Lerato Moloi, 27, found murdered in Soweto; PopiQwabe, 24, died in hospital after she was shot; Bongeka Phungula, 28, was raped, shot and killed in Soweto; Courtney Pieters, 3 , her body was found in a shallow grave, raped and killed by a male renting a space in her family's home. These are only a few examples of how women suffer under a patriarchal cultural system (Pitoos 2017).
Karant-Nunn and Wiesner-Hanks (2003:8) say that '[c]hurches today, both Protestant and Catholic, are still wrestling with the balance between men's and women's spiritual equality and social difference'. The structures of cultural patriarchy supported by the leaders of the church, whether directly or indirectly, are one of the principal reasons why women still suffer violence, inequality and subordination.

Ani (2011:21-23) states that for millennia it was believed that God directed and the Bible supported the unequal status and inferiority of women as second-class citizens in relation to men. These views in the cause of history also contributed to the exclusion of women in the church in South African contexts.

Although the positioning of women in the church is not distinctive of apartheid, it is a universal devaluation of women. The church in South Africa positioned women in inferior ways; man was viewed to be created in the image of God; Adam was created first and then Eve from Adam's rib; and not only was she guilty of tempting Adam, she was weaker and lesser than him and she became the cause of the Fall. The church upheld these stereotypical beliefs, and regulated and assigned a subordinate status to women.

We already noted that the interpretation of biblical texts were carried out by men, specifically men who were inspired by God's word and who viewed God's word as infallible. However, the church was, and some are still today, dogmatically inspired by wrong and misinterpreted views of women's status and oppression in society. Women were denied rights based on faulty interpretations of scripture and suffered under customary mores and traditions (Casimir et al. 2014:167).

Although South Africa's constitution grants women full and equal status, this is not always the case within some church societies. Many women are still denied full participation in all roles in the church. For example, the Catholic Church does not appoint women bishops and archbishops. Sadly, women's issues such as rape, abortion and birth control are often dealt with by males.

In South Africa, women endured the same prejudice and inequality as women in other countries. The colonial church was originally considered to be a liberator in the restoration of women's rights, but it supported and endorsed the ancient views on women as inferior beings and maintained its views on women's subordination, equality and injustice (Casimir et al. 2014:167). The church, as a guardian against women's oppression, did not fulfil its role to protect women from any form of oppression or harm.

In her presentation to the Truth and Reconciliation Commission Faith Communities hearing (1997), Makhene told the committee that all religions are patriarchal, and as the missionaries reinforced this view, women remained powerless and voiceless. She also stated that spirituality, 
prayers and worship in the church promote male dominance and that the language of religion is male, that God is male and that scripture promotes male dominance. Although women are more predominant in the church, men are the ruling sex in the church. Not only are women excluded from visibility in the liturgy and hymns of the church, but also from the Christian language, where people are referred to as 'sons of God', 'brothers', 'Lord', 'Master', 'King' and 'Father'.

Makhene (1997) also stated that male language and imagery contributed to the domination of women. Referring to the early church's views on women as misbegotten males, as evil and as the devil's doorway, she points out that these views were misogynistic in nature. Scripture is manipulated to silence, humiliate and marginalise women. The nature of the church structures is occupied mainly by men, who condoned, encouraged and enforced the subjugation of women, which resulted in their full potential being denied in the spheres of the church, economy, politics and society.

\section{Conclusion}

The old woman's story can be applied to the church. There are numbers above 100, and the church may not persist in ignorance of women's inequality. To prevent women's marginalisation and victimisation, the church has a pivotal role and responsibility to redefine gender roles that affect justice and equality for women. With that said, the church has the enormous task of undoing the unjustness bestowed upon women over the years and not keeping people ignorant of the full potential and equality of women.

According to Deuteronomy 20:19, man is a tree of the field. Referring back to the tree metaphor of Johnson, I propose the following metaphor of the church as the tree of gender equality. The church has to confront its views on gender inequality and must put measures in place to sanction women's equality (see Figure 1).

The roots in the tree represent patriarchy and symbolise ideologies, beliefs, values, inequality, religions, greed and culture within the family, the economy, in politics, in education and in the arts. Patriarchy is rooted in the ideology of male control, supremacy, identification and centeredness. According to Johnson (2014), the roots of the tree are represented as follows:

... religious leaders, school principals, members of legislatures at all levels of government, senior law partners, tenured professors, generals and admirals, and even those identified as 'head of household' all tend to be male under patriarchy. (p. 7)

Patriarchy is interpreted to be antiwoman and oppressive in nature, and it upholds male dominance and male power. It often results in the right of men to dominate and to control.

The church resembles the trunk of the tree and should challenge patriarchal structures and cultures more visibly

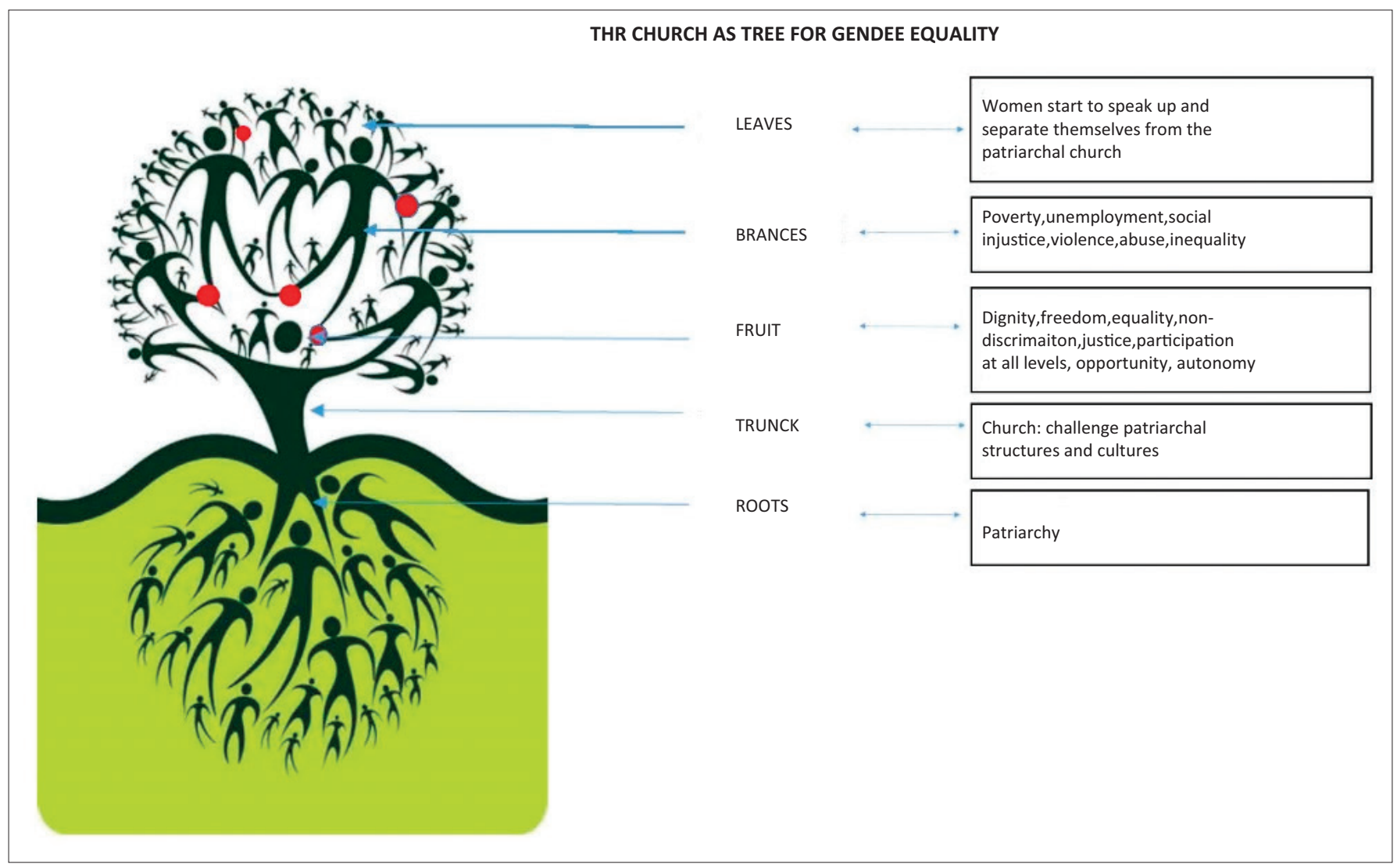

Source: Image adapted from Keal, S., Keal, S. \& Profile, V., 2018, Trees and perceptions, Theologikeal.blogspot.com, viewed 05 July 2018, from http://theologikeal.blogspot.com/2010/08/trees-andperceptions.html

FIGURE 1: The church as the tree of gender equality. 
and head on where women are still living under patriarchal rule. Although the church addresses patriarchal oppression and the dehumanisation of women, there is more to be done to truly ensure equality for women in all spheres of life. The church should create safe spaces where women, as well as men, can be guided away from patriarchal tendencies and should assist its members and the broader society to acknowledge the injustice that the patriarchal system bestows upon women. This can be done through education and community outreach programmes in which society can be educated to participate in the changing of unjustness that women suffer because of the ideology of male control, supremacy and identification.

The branches of the tree represent poverty, unemployment, social injustice, violence, abuse, the inequality that results in unethical and cultural mistrust, prejudice, genderbased violence and abuse. Many women still suffer from inequality, and it is visible almost every day in reports in the media. These issues need to be addressed urgently to bring discrimination and marginalisation of women to an end.

In the tree metaphor, women represent the leaves of the tree that help to generate the life of the tree. Collectively the leaves have an important role, and that is to nourish the tree. Women, as well as the church collectively, have to take responsibility for changing discrimination and marginalisation.

The patriarchal tree cannot bear fruit where the roots, the trunk, the branches and the leaves are unhealthy.

The church as a tree can change society's views on women's human rights and gender equality by restoring women's dignity, equality, non-discrimination, justice, opportunity and autonomy.

The church should leave no stone unturned to address patriarchal systems that have undermined women's dignity. Robinson (2012), for example, states that:

Violence against women is a health issue and a development issue. It also flies in the face of God-given human dignity and is, therefore, an urgent Gospel issue. (p. 3)

The church has to be an active participant in the restoration of women's dignity through addressing the complex and core principals of masculine control, dominance, identification, centeredness that still prevail in the church and society. The church has the task of transforming the patriarchal roots in society into roots of empathy, caring, healing and equality to protect women from all forms of discrimination, in order for women to be able to be worthy participants in all spheres of life. Therefore the church has to confront the roots of all patriarchal systems that still have an effect on women's dignity.

Not only does the church have to address women's dignity, but the church has the huge task of addressing women's inequality. Women have to be empowered to fulfil an integral part of national development, peace building and conflict resolution. Women can bridge inequalities in the private and public spheres. Women's equality is proof of a democratic society, wherein they can participate in the economic, political, social and cultural spheres without being subjected to patriarchal oppression and discrimination.

Gender equality necessitates the absence of discrimination on account of a person's gender in order to have access to opportunities, resources and benefits. The church must not tolerate discrimination; women need to be freed from living at the margin of society or else they will stay dependant on men.

Inequality leads to injustice. Through its doctrines, practices and leadership, the church has to play an important role in the struggle against injustice. Women also have a role to play in fighting injustice, and the more they speak up against injustice, the more it will contribute to changing and transforming societal inequality.

The church has to acknowledge that it should empower women to view themselves as worthy human beings in the eyes of God and that they are free to be agents in the Kingdom of God, that they may demand respect and access to equal opportunities within the church and society at large.

Gender inequality is a crime against women and society, and for change to happen, it will have to start within the church.

Regardless of the presence of gender inequality in some churches today, I concur with Pierce and Groothuis (2014), who say:

Women and men were created equally (Gen 1:27); they have equally fallen into sin (Rom 3:23); they are equally redeemable through Christ's life, death, and resurrection (Joh 3:16); both male and female are equal in participating in the new covenant (Gal 3:28) and they are equal heirs of God in Christ (1 Pet 3:7). Both men and women are equally responsible for life and ministry as empowered human beings through the Holy colonial Spirit (Acts 2:17). (p. 13)

\section{Acknowledgements Competing interests}

The author declares that she has no financial or personal relationship(s) that may have inappropriately influenced her in writing this article.

\section{References}

Ani, C.K.C., 2011, Rethinking gender and women empowerment in Africa, TAISSE Publishers, Ndola.

Casimir, A., et al., 2014, 'The church and gender equality in Africa: Questioning culture and the theological paradigm on women oppression', Open Journal of Philosophy 4, 166-173. https://doi.org/10.4236/ojpp.2014.42024

Collins, H., 2010, Women's leadership in the early church, Oxford University Press, London.

De Conick, A.D., 2011, Holy misogyny: Why the sex and gender conflicts in the early Church still matter, Continuum International Publishing Group, London. 
Department of Women, Children and People with Disabilities (DWCPD), 2014, Stop violence against women in South Africa, DWCPD and UNFPA, Pretoria.

Endendijk, J., Groeneveld, M., Berkel, S., Hallers-Hallboom, E. \& Mesman, J., 2013 'Gender stereotypes in the family context: Mothers, fathers, and siblings', Sex roles 68, 577-590. https://doi.org/10.1007/s11199-013-0265-4

French, M., 1985, Beyond power: On women, men and morals, Ballantine Books, New York.

Hadebe, N., 2007, Gender, gender equality, and the church, Ecumenical Women at the United Nations, viewed 03 July 2017, from https://ecumenicalwomen org/ theology/academic-articles/gender-gender-equality-and-the-church-by-nantondohadebe/

Jeffreys, S., 2002, Man's dominion: The rise of religion and the eclipse of women's rights, Routledge, New York.

Johnson, A.G., 2014, The gender knot: Unraveling our patriarchal legacy, Revised and updated edition, Temple University, Philadelphia, PA.

Jones, S., 2000, Feminist theories and Christian theology: Cartographies of grace Fortress Press, Minneapolis, MN.

Karant-Nunn, S.C. \& Wiesner-Hanks, M.E., 2003, Luther on women. A sourcebook, Cambridge University Press, Cambridge.

Keal, S., Keal, S. \& Profile, V., 2018, Trees and perceptions, Theologikeal.blogspot.com, viewed 05 July 2018, from http://theologikeal.blogspot.com/2010/08/trees-andperceptions.html

Kimball, C.N., 2004, 'Nature, culture and gender complementarity', in R.W. Pierce \& R.M. Groothuis (eds.), Discovering biblical equality: Complementarity without hierarchy, pp. 464-480, Intervarsity Press, IL.

Klingorová, K. \& Harvlíček, T., 2015, 'Religion and gender inequality: The status of women in the societies of the world religions', Moravian Geographical Reports 23 2-11. https://doi.org/10.1515/mgr-2015-0006

Livermore, D.A., 2009, Cultural intelligence, improving your CQ to engage our multicultural word, Baker, Grand Rapids, MI.

Landman, C., 2009, 'Religious discourses supporting patriarchy', in The evil of patriarchy in church, society and politics, A Consultation Held at Mount Fleur Conference Center Stellenbosch 5 and 6 March 2009. Hosted by Inclusive and Affirming Ministries (IAM), in partnership with the Department of Religion and Theology of the University of the Western Cape, and the Centre for Christian Spirituality, pp. 37-44

Laurien, A., 2004, 'Patriarchy', in G.R. Goethals, G.J. Sorenson \& J.M. Burns (eds.), Encyclopaedia of leadership, 15 September 2007, viewed 04 March 2011, from http://www.sage-ereference.com/leadership/Article_n269.html/

Lorber, J., 2010, Gender inequality: Feminist theories and politics, Oxford University Press, New York.

Louw, D., 2009, 'From phenomenology to ontology in the gender debate: "Feminine" without "Femininity" beyond "Feminism"?', in N.P. Miranda, S. Nadar \& C. Le Bruyns (eds.), Ragbag theologies: Essays in honour of denise ackermann: A theologian of praxis, SUN Media, Stellenbosch.

Macdonald, M., 2010, Real women through letters of St Paul, Cambridge University Press, London.
Madlala-Routledge, N., 2009, 'Reconciliation between men and women', in The evil of patriarchy in church, society and politics, A Consultation Held at Mount Fleur Conference Center Stellenbosch 5 and 6 March 2009. Hosted by Inclusive and Affirming Ministries (IAM), in partnership with Theology of the University of the Western Cape, and the Centre for Christian Spirituality, Stellenbosch, pp. 1-50.

Makhene, C.M., 1997, In the truth and reconciliation commission faith communities hearing, 17-19 November 1997-Part 2, 7 November 1997, South Africa, East London, viewed 15 August 2017, from http://www.justice.gov.za/trc/media/pr/ 1997/p971107c.htm

Maseno, L. \& Kilonzo, S.M., 2011, ‘Engendering development: Demystifying patriarchy and its effects on women in rural Kenya', International Journal of Sociology and Anthropology 3(2), 45-55.

Njoroge, N., 2009, Gender justice, ministry and healing: A Christian response to the HIV pandemic, Progressio, London.

Omoyibo, K.U. \& Ajayi, B.I., 2011, 'Understanding gender and global Africa: A critical perspective', Gender and Behaviour 9(1), 3729-3752. https://doi.org/10.4314/ gab.v9i1.67470

Owanikin, R.M., 2006, 'The priesthood of church women in the Nigerian context', in M.A. Oduyoye \& M.R.A. Kanyordo (eds.), The will to arise. Women, tradition and the church in Africa, pp. 206-220, Cluster, Pietermaritzburg (2006-2019).

Pierce, R.W. \& Groothuis, R.M. (eds.), 2004, Discovering biblical equality. Complementarity without hierarchy, Intervarsity Press, IL.

Pitoos, I., 2017, 'South Africa: A country where women and children end up as grim stats', News24, 22 May 2017, viewed 03 June 2018, from https://www.news24. com/SouthAfrica/News/south-africa-a-country-where-women-and-children-endup-as-grim-stats-20170522

Remedios, M.C., 2016, 'The changing gender roles in early Christianity', Journal of Humanities and Social Science 21(10), 7-10.

Ridgeway, C., 2004, 'Unpacking the gender system: A theoretical perspective on gender beliefs and social relations', Gender and Society 18(4), 510-531. https:// doi.org/10.1177/0891243204265269

Robinson, T., 2012, Anglican communion publication - Resource on the 16 days campaign, viewed 21 May 2018, from www.anglicancommunion.org/media/ 62876/16_days_resource_2013.pdf

Shonayin, L., 2012, The African report, No. 44, p. 98, GroupeJeuneAfrique, Paris.

Statistics South Africa, 2017, South Africa demographic and health survey 2016: Key indicator report, media release, Statistics South Africa, South Africa, viewed 03 June 2018, from http://www.statssa.gov.za/?p=9836

Stump, R., 2008, The geography of religion: Faith, place, and space, Rowman and Littlefield Publishers, Lanham, MD.

Theron, P., 2015, 'Cultural perspectives on gender equality: Preliminary indicators for the Christian church in Sub-Saharan Africa', in E. Mouton, G. Kapuma, L. Hansen \& T. Togom (eds.), Living with dignity: African perspectives on gender equality, Sun Media, Stellenbosch, South Africa.

Witherington, B., 1985, Women in the ministry of Jesus, University Press, Cambridge.

Wood, J.M., 2012, 'Patriarchy, feminism and Mary Daly: A systematic-theological enquiry into Daly's engagement with gender issues in Christian theology', Unpublished doctoral thesis, University of South Africa, Pretoria. 